\title{
Toxicological changes in female Wistar albino rats exposed to Solignum: a permethrin-containing wood preservative
}

\author{
K. C. Patrick-Iwuanyanwu, ${ }^{1,2, *}$, G. E. Bekibele ${ }^{1,2}$, C. Egbuna ${ }^{2}$ and F. C. Anacletus ${ }^{1,2}$ \\ ${ }^{1}$ Department of Biochemistry, University of Port Harcourt, Choba, Rivers State; \\ ${ }^{2}$ Africa Center of Excellence in Public Health and Toxicological Research (ACE-PUTOR), \\ University of Port Harcourt, Rivers State, Nigeria.
}

\begin{abstract}
This study sought to establish the effects of sub-chronic exposure of female albino rats to permethrin, a major constituent in Solignum. Thirty-two female rats were randomly divided into four groups (containing 8 rats each): control and three Solignum treatment concentrations (100, 200, and $400 \mathrm{mg} / \mathrm{kg}$ body weight (BW)) per day orally for four weeks. Results indicated a significant $(\leq 0.05)$ increase in the body weight of rats in the 100,200 , and $400 \mathrm{mg} / \mathrm{kg}$ BW groups compared to the control group. Biochemical analysis showed a significant $(\leq 0.05)$ increase in serum $\mathrm{Na}^{+}$(100 and $400 \mathrm{mg} / \mathrm{kg}$ treatment groups), and urea concentration (400 mg/kg only), while the creatinine, $\mathrm{K}^{+}$, and $\mathrm{Cl}^{-}$levels significantly $(\leq 0.05)$ reduced in comparison with the control group. Serum bilirubin, total protein, glyceraldehyde, and cholesterol concentrations for most of the treatment groups increased significantly $(\leq 0.05)$ when compared with control. Haematological parameters recorded a significant $(\leq 0.05)$ increase in the red blood cells count ( 200 and $400 \mathrm{mg} / \mathrm{kg}$ groups), the packed cell volume PCV (200 mg/kg only), mean corpuscular volume (MCV) and mean corpuscular haemoglobin (MCH) of the $200 \mathrm{mg} / \mathrm{kg}$ and $400 \mathrm{mg} / \mathrm{kg}$ compared to the control group, and the haemoglobin concentration for test groups were significantly $(\leq 0.05)$ lower than the control
\end{abstract}

\footnotetext{
*Corresponding author

kc.patrick-iwuanyanwu@uniport.edu.ng
}

group. There was a significant $(\leq 0.05)$ difference in the mean corpuscular haemoglobin concentration (MCHC) and white blood cell count (WBC) of all test groups compared to the control group. The platelet count, lymphocyte and neutrophil concentration were significantly $(\leq 0.05)$ higher than the control, while there was a significant $(\leq 0.05)$ reduction in monocyte count in a dosedependent manner across the three test groups in comparison to the control. Histopathological examination of hepatocytes, kidneys, and ovarian tissues revealed variations from the control rats. This study shows that some biochemical, hematological, and histological changes can occur when there is sub-chronic exposure to the commercial wood preservative, Solignum.

KEYWORDS: Solignum, permethrin, toxicity, sub-chronic exposure, wood preservative, histological examination.

\section{INTRODUCTION}

One wood preservative with widespread industrial application in carpentry, furniture making, and in homes, is Solignum with its major constituent being permethrin [1]. Permethrin (( \pm$)-3$ phenoxybenzyl 3-(2,2-dichlorovinyl)-2,2 dimethyl cyclopropane carboxylate) is a synthetic agent, of the pyrethroid family widely used as an insecticide, which possesses a structural resemblance to natural pyrethrins [2]. Permethrin, as an insecticide is preferred over other insecticides because it can be used for targeted effect studies of specific 
insect classes [3]; also studies have shown them to induce minimum toxic effects than organochlorine, organophosphate, and methylcarbamate insecticides to mammals. Their rapid absorption and slower detoxification also contribute to the considerations for their usage as insecticides, accounting for its widespread applications in agricultural, veterinary, medical, and household settings [4]. It has found applications in mosquito control programs, hair treatment for head lice infestations, for human use in pediculicides and scabicides, as well as in coating clothing to ward off ectoparasites [2].

Insecticide use could generate problems for animals when plants coated with these compounds are consumed, and also through indirect exposures. There is also the likelihood of contaminating surface water following run-offs from heavy rainfall. This contamination may not necessarily lead to instant death but may have significant effects that can lead to physiological stress and organ dysfunction in animals [5].

Dikshit [6] describes the harmful effects associated with pesticide exposure, which may include acute and chronic toxicological events in liver, kidney, heart, and hormonal disorders, as well as mutagenic and carcinogenic events. Pyrethroid insecticides are known to be lipophilic and this may go on to account for why they are quickly absorbed through the gastrointestinal and respiratory tracts enabling selective distribution into tissues with abundant supply of lipids, body fat, skin, liver, kidney, ovaries, the central and peripheral nervous systems inclusive [7]. Kanber et al., Duzguner and Erdogan $[8,9]$ recorded that some compounds used in pesticide production can induce oxidative stress leading to the generation of free radicals and may result in changes in antioxidants or free radical scavenging enzyme systems. Deltamethrin-induced toxicity in the reproductive system as well as endocrine disruption, have been reported in numerous studies [10].

Very few studies exist that considered the hepatotoxic, nephrotoxic, reproductive, and hematological effects of known wood preservatives. This study sought to establish the hepatotoxic, nephrotoxic, hematological, and reproductive implications of sub-chronic exposure to permethrin, a major constituent in Solignum $^{\circledR}$, a wood preservative, on female rats.

\section{MATERIALS AND METHODS}

\section{Study design}

One gallon of Solignum wood preservative used in this study was purchased from the Timber section of Mile 3 Market, while Goya ${ }^{\circledR}$ Olive oil was purchased from Everyday Emporium Super Market, all in Port Harcourt, Rivers State, Nigeria. Thirty-two adult female Wistar albino rats weighing between 110 and $120 \mathrm{~g}$ used in this study were purchased from the Animal House of the Department of Biochemistry, University of Port Harcourt, Rivers State Nigeria. They were housed in individual cages and allowed to acclimatize under laboratory conditions at room temperature for 7 days before the experiment commenced. They were kept under hygienic and standard approved conditions, and maintained under a $12 \mathrm{~h}$ light/12 h dark cycle, with pelletized rat feeds (UAC Vital Feeds ${ }^{\circledR}$, Nigeria) and water made accessible ad libitum.

Reports have shown that the $\mathrm{LD}_{50}$ for Permethrin in rats ranges from $430 \mathrm{mg} / \mathrm{kg}-4000 \mathrm{mg} / \mathrm{kg}$ $[11,12]$. Therefore, $1 / 10$ of the upper range (400 $\mathrm{mg} / \mathrm{kg}$ ) was selected as the highest dose in this study. The animals were divided into four (4) groups of eight (8) animals per group in a random fashion. Group I (control) received feed and $1 \mathrm{ml}$ olive oil only. Group II received feed and $100 \mathrm{mg} / \mathrm{kg}$ BW Solignum orally daily dissolved in olive oil at a ratio of 1:1. Group III received feed and $200 \mathrm{mg} / \mathrm{kg}$ BW Solignum dissolved in olive oil at a 1:1 ratio, and administered daily. Group IV received feed and $400 \mathrm{mg} / \mathrm{kg}$ BW Solignum dissolved in olive oil at a 1:1 ratio, and administered daily. The experimental animals were sustained under normal diet and water ad libitum all through the experiment. In the course of the four-week experimental period, all groups were daily observed for signs of adverse changes and mortality patterns. The animals were weighed weekly and body weight variations were recorded with the use of Organisation for Economic Cooperation and Development (OECD)-specified sensitive balance [13].

All animals were sacrificed after four weeks of treatment. Rats were not fed overnight, twentyfour hours after the conclusion of the experiment, after which they were anaesthetized in a 
chloroform-saturated chamber and then sacrificed by the use of the cervical dislocation method. Blood samples were obtained by cardiac puncture from each rat using a $2 \mathrm{~mL}$ hypodermic syringe and needle. The blood samples were collected in an anticoagulant-free bottle for serum biochemical parameters. Serum was separated by centrifugation at $2500 \mathrm{rpm}$ for $10 \mathrm{~min}$ and stored in a refrigerator at $4{ }^{\circ} \mathrm{C}$ pending use.

\section{Biochemical analysis}

Total and direct bilirubin was estimated using the Humazym MUV colorimetric test kits. Serum total protein was measured by Biuret method, while cholesterol level and triglyceride concentrations were estimated by an enzymatic colorimetric method as earlier described in [14], using a spectrophotometer (Model AA200; Shimadzu, Tokyo, Japan). Blood urea was estimated by an enzymatic method [15], while serum creatinine was determined according to the method described by Faulkner and King [16].

The analysis was done using an auto analyzer. The samples were labeled and arranged according to their numbers. $50 \mu \mathrm{l}$ of the plasma was put into each of the sample cups of the auto analyzer using a micropipette; they were arranged in the auto analyzer according to their numbers. The reagent for each test was put in the auto analyzer reagent bottle and arranged in the position for the reagent. Sodium-ion, potassium ion, chloride ion, Urea, and creatinine were selected on the main screen, after which an analysis of the aspirated samples was run by the auto analyzer. Results were displayed at the conclusion of the analysis.

\section{Histopathological examination}

A portion of the liver, kidney, and ovaries of all the rat groups were dissected out and fixed in 10\% buffered neutral formalin for 48 hours followed by a bovine solution for 6 hours and then processed for paraffin embedding. By the use of a microtome, parts of $5 \mu \mathrm{m}$ thickness were obtained, processed in alcohol-xylene series, and were stained with alum-hematoxylin and eosin [17] and subjected to histopathological examination.

\section{Statistical analysis}

The mean \pm S.E.M was determined for each parameter. Total variations present in a set of data were estimated by one-way analysis of variance (ANOVA), followed by Dunnet's test. $\mathrm{P} \leq 0.05$ was judged as statistically significant in comparison to control.

\section{RESULTS}

After four weeks of oral exposure of the test animals to Solignum at doses of 100, 200 and 400 $\mathrm{mg} / \mathrm{kg} \mathrm{BW}$, no death was recorded. There were no signs of changes in skin, fur, eyes and nasal mucosa, respiratory rate, heart rate and blood pressure, autonomic effects and central nervous system among the exposed rats. The effects of the oral administration of Solignum on the body weight of female Wistar albino rats are presented in Figure 1. There was a significant $(p \leq 0.05)$ increase in the body weight of female rats across all groups up to the third week. However, there was an observable decline in body weight of female rats administered $400 \mathrm{mg} / \mathrm{kg} \mathrm{BW}$ of Solignum when compared with control.

The results of the effects of oral administration of different concentrations of Solignum on biochemical parameters in female albino rats are presented below (Table 1). The sodium ion $\left(\mathrm{Na}^{+}\right)$ concentration significantly $(\leq 0.05)$ increased in rats administered $100 \mathrm{mg} / \mathrm{kg}$ and $400 \mathrm{mg} / \mathrm{kg}$ concentrations of Solignum unlike the control. However, rats administered $200 \mathrm{mg} / \mathrm{kg}$ of Solignum showed a decrease in $\mathrm{Na}^{+}$concentration. The potassium ion $\left(\mathrm{K}^{+}\right)$concentration was significantly $(\leq 0.05)$ decreased in a dose-dependent manner across all groups unlike the control group, whereas the chloride ion $\left(\mathrm{Cl}^{-}\right)$and creatinine concentrations were significantly ( $\mathrm{p} \leq 0.05$ ) lower for all groups compared to the control group. Urea on the other hand increased significantly $(\leq 0.05)$ in the $400 \mathrm{mg} / \mathrm{kg}$ experimental group when compared to the control. The conjugated and total bilirubin levels of rats administered $100 \mathrm{mg} / \mathrm{kg}$ and $400 \mathrm{mg} / \mathrm{kg}$ Solignum were significantly ( $p \leq 0.05$ ) elevated when compared to the control, unlike the $200 \mathrm{mg} / \mathrm{kg}$ exposure group. The total protein concentration was significantly $(\mathrm{p} \leq 0.05)$ higher for the $200 \mathrm{mg} / \mathrm{kg}$ and $400 \mathrm{mg} / \mathrm{kg}$ test group in comparison to the control group. There was a slight increase in the glyceraldehyde concentrations of the test groups. However, there was no significant difference between the test groups and the control. 


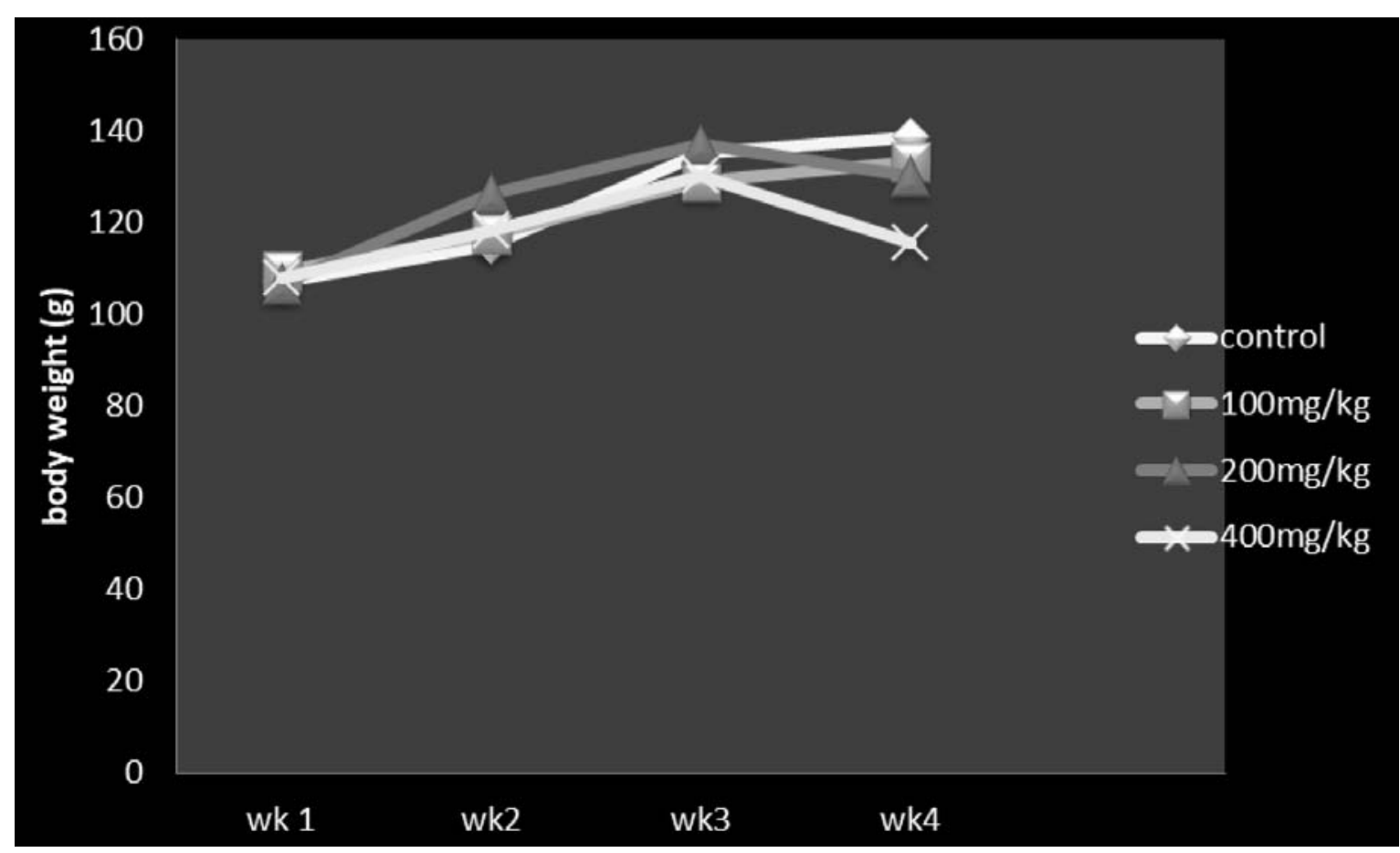

Figure 1. Results of the weekly intake of Solignum ${ }^{\circledR}$ administered to tested female rats per body weight for 28 days and control group.

Table 1. Results of the effect of Solignum ${ }^{\circledR}$ on selected biochemical parameters.

\begin{tabular}{|l|c|c|c|c|}
\hline Parameters & Control & $\mathbf{1 0 0} \mathbf{~} \mathbf{~ g} / \mathbf{k g}$ & $\mathbf{2 0 0} \mathbf{~ m g} / \mathbf{k g}$ & $\mathbf{4 0 0} \mathbf{~ m g} / \mathbf{k g}$ \\
\hline $\mathrm{Na}^{+}(\mu / \mathrm{l})$ & $140.0 \pm 2.31$ & $142.50 \pm 1.73$ & $135.0 \pm 8.04$ & $141.80 \pm 5.56$ \\
\hline $\mathrm{K}^{+}(\mu / \mathrm{l})$ & $8.95 \pm 1.79$ & $8.15 \pm 2.57$ & $8.08 \pm 4.66$ & $7.88 \pm 1.39$ \\
\hline $\mathrm{Cl}^{-}(\mu / \mathrm{l})$ & $122.00 \pm 11.55$ & $109.8 \pm 12.26$ & $119.5 \pm 25.84$ & $111.0 \pm 9.52$ \\
\hline Urea $(\mu / \mathrm{l})$ & $5.60 \pm 0.81 \mathrm{~S}$ & $4.88 \pm 0.93$ & $5.28 \pm 1.05$ & $6.025 \pm 1.03$ \\
\hline Creatinine $(\mu / \mathrm{l})$ & $75.95 \pm 15.76$ & $46.05 \pm 10.33$ & $64.65 \pm 18.50$ & $61.75 \pm 4.00$ \\
\hline C. bilirubin $(\mathrm{mmol} / \mathrm{L})$ & $0.50 \pm 0.289$ & $3.78 \pm 2.09$ & $0.80 \pm 0.57$ & $1.08 \pm 0.138$ \\
\hline T. bilirubin $(\mathrm{mmol} / \mathrm{L})$ & $2.50 \pm 1.44$ & $7.25 \pm 2.71$ & $2.50 \pm 1.50$ & $3.73 \pm 0.48$ \\
\hline T protein $(\mathrm{mmol} / \mathrm{L})$ & $67.35 \pm 0.38$ & $62.50 \pm 5.33$ & $68.75 \pm 8.23$ & $69.25 \pm 3.01$ \\
\hline Glyceride $(\mathrm{mmol} / \mathrm{L})$ & $1.02 \pm 0.06$ & $1.20 \pm 0.06$ & $1.09 \pm 0.13$ & $1.31 \pm 0.11$ \\
\hline Cholesterol $(\mathrm{mmol} / \mathrm{L})$ & $1.42 \pm 0.09$ & $1.46 \pm 0.13$ & $1.81 \pm 0.25$ & $1.56 \pm 0.09$ \\
\hline
\end{tabular}

The data are expressed as mean \pm standard error mean $(\mathrm{SEM})(\mathrm{n}=8)$.

The results of the effect of oral administration of Solignum on haematological parameters are captured in Table 2 . The red blood cell count of rats administered 200 and $400 \mathrm{mg} / \mathrm{kg} \mathrm{BW}$ of Solignum increased significantly, whereas a decrease in red blood cell count in rats administered 100 $\mathrm{mg} / \mathrm{kg}$ BW of Solignum ${ }^{\circledR}$ was observed when compared to the control. There was a significant $(\mathrm{p} \leq 0.05)$ decrease in haemoglobin concentration in rats administered $400 \mathrm{mg} / \mathrm{kg} \mathrm{BW}$ when 
Table 2. Results of haematological parameters in female rats exposed to Solignum ${ }^{\circledR}$.

\begin{tabular}{|l|c|c|c|c|}
\hline Parameters & Control & $\mathbf{1 0 0} \mathbf{~ m g} / \mathbf{k g}$ & $\mathbf{2 0 0} \mathbf{~ m g} / \mathbf{k g}$ & $\mathbf{4 0 0} \mathbf{~ m g} / \mathbf{k g}$ \\
\hline RBC $\left(10^{12} / \mathrm{L}\right)$ & $44.00 \pm 34.64^{\mathrm{a}}$ & $39.75 \pm 27.11^{\mathrm{b}}$ & $88.25 \pm 158.27^{\mathrm{c}}$ & $81.00 \pm 48.93^{\mathrm{c}}$ \\
\hline HB (g/L) & $15.20 \pm 1.155^{\mathrm{a}}$ & $13.85 \pm 3.367^{\mathrm{a}}$ & $14.48 \pm 1.758^{\mathrm{a}}$ & $12.98 \pm 2.398^{\mathrm{b}}$ \\
\hline PCV (L/L) & $42.50 \pm 14.041^{\mathrm{a}}$ & $41.60 \pm 10.06^{\mathrm{a}}$ & $44.00 \pm 5.354^{\mathrm{b}}$ & $39.25 \pm 7.411^{\mathrm{a}}$ \\
\hline MCV (fL) & $51.20 \pm 1.155^{\mathrm{a}}$ & $50.78 \pm 3.211^{\mathrm{a}}$ & $48.90 \pm 2.195$ & $52.38 \pm 2.573^{\mathrm{b}}$ \\
\hline MCH (pg) & $18.60 \pm 0.346^{\mathrm{a}}$ & $18.73 \pm 1.053^{\mathrm{a}}$ & $18.93 \pm 0.655^{\mathrm{a}}$ & $19.48 \pm 1.037^{\mathrm{b}}$ \\
\hline MCHC (g/L) & $18.60 \pm 0.346^{\mathrm{a}}$ & $36.95 \pm 1.611^{\mathrm{b}}$ & $38.83 \pm 2.336^{\mathrm{b}}$ & $37.18 \pm 0.793^{\mathrm{b}}$ \\
\hline WBC $\left(10^{9} / \mathrm{L}\right)$ & $3.700 \pm 1.848$ & $3.800 \pm 1.319$ & $6.150 \pm 1.710$ & $4.100 \pm 2.557$ \\
\hline Platelet $\left(10^{9} / \mathrm{L}\right)$ & $44.00 \pm 42.43^{\mathrm{a}}$ & $39.75 \pm 29.11^{\mathrm{a}}$ & $88.25 \pm 58.27^{\mathrm{b}}$ & $81.00 \pm 48.93^{\mathrm{a}}$ \\
\hline Monocyte & $80.00 \pm 12.99^{\mathrm{a}}$ & $73.50 \pm 11.03^{\mathrm{a}}$ & $61.50 \pm 9.579^{\mathrm{b}}$ & $46.50 \pm 3.500^{\mathrm{c}}$ \\
\hline Neutrophil $\left(10^{9} / \mathrm{L}\right)$ & $7.95 \pm 1.097^{\mathrm{a}}$ & $10.2 \pm 1.900^{\mathrm{b}}$ & $10.05 \pm 1.597^{\mathrm{b}}$ & $8.025 \pm 3.960^{\mathrm{b}}$ \\
\hline Lymphocyte $\left(10^{9} / \mathrm{L}\right)$ & $76.15 \pm 3.984^{\mathrm{a}}$ & $74.88 \pm 4.116^{\mathrm{a}}$ & $77.38 \pm 4.966^{\mathrm{b}}$ & $80.73 \pm 8.248^{\mathrm{b}}$ \\
\hline
\end{tabular}

The data are expressed as mean \pm standard error mean $(\mathrm{SEM})(\mathrm{n}=8)$. Means with different superscripts are considered to be significantly different at $\mathrm{p} \leq 0.05$.

compared to the control group. The packed cell volume (PCV) of the $200 \mathrm{mg} / \mathrm{kg}$ test group was significantly $(\mathrm{p} \leq 0.05)$ higher than the control group. Mean corpuscular volume (MCV) and mean corpuscular haemoglobin (MCH) of the 400 $\mathrm{mg} / \mathrm{kg}$ test group was significantly $(\mathrm{p} \leq 0.05)$ higher than the control. There was a significant $(\mathrm{p} \leq 0.05)$ difference in the mean corpuscular haemoglobin concentration (MCHC) and white blood cell count (WBC) in all test groups compared to the control group. The platelet count and lymphocyte for the $200 \mathrm{mg} / \mathrm{kg}$ and $400 \mathrm{mg} / \mathrm{kg}$ test groups were significantly $(\mathrm{p} \leq 0.05)$ higher than the control, while the monocyte count dropped significantly $(\mathrm{p} \leq 0.05$ ) in a dose-dependent manner across the three test groups in comparison to the control. The neutrophil concentration of the three test groups were significantly $(\leq 0.05)$ increased in comparison to the control group.

Histopathological examination of the liver, kidneys, and ovaries are shown in Figures 2-4. Hepatocytes of the control group showed normal architecture whereas rats exposed to $100 \mathrm{mg} / \mathrm{kg}$, $200 \mathrm{mg} / \mathrm{kg}$, and $400 \mathrm{mg} / \mathrm{kg}$ of Solignum were characterized by mild periportal inflammatory cells and cytoplasmic degeneration (Figures 2a-d). Kidneys of control rats also showed normal architecture whereas treatment with different concentrations of Solignum ${ }^{\circledR}$ showed the presence of inflammatory cells, congested vessels, and interstitial hemorrhage (Figures 3a-d). Ovarian tissues of control rats had a normal architecture, unlike the test groups which had atrophic follicles, blood vessel haemorrhage and degenerating follicles (Figures 4a-d).

\section{DISCUSSION}

The liver and kidney are key organs that aid in the detoxification and elimination of waste products from the body. Exposures to chemical agents or generally toxins can induce stress which could hamper the functionality of these vital organs [18]. Permethrin, the active chemical compound in Solignum has gained wide acceptance for use in agricultural and domestic settings. The organic compounds that constitute most insecticides have been found to result in organ, tissue, and DNA damage. They trigger certain processes like carcinogenesis, necrosis, inflammation, and apoptosis [19]. Irrespective of the findings pointing to the fast metabolism and almost non-accumulation of members of the pyrethroid family, adverse health effects from chronic exposures have been reported to exist in current studies [20] and are consistent with the observed effects in the present study. 


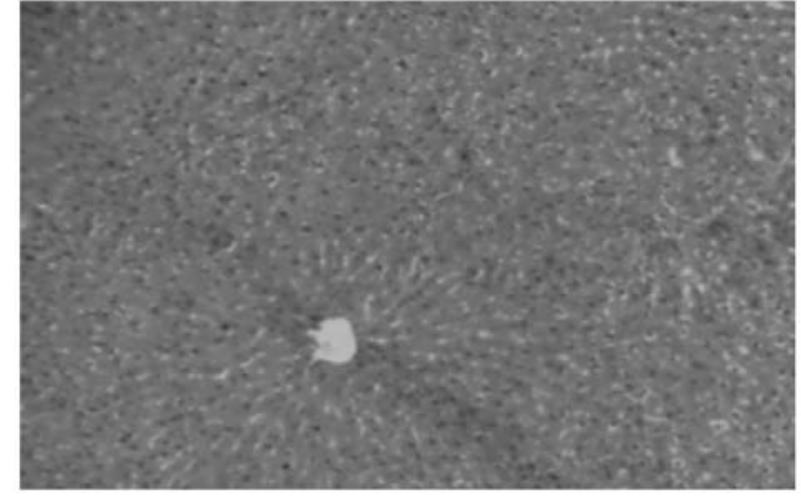

a

A section of the rat liver tissues showing normal architecture in control rats (X400) liver

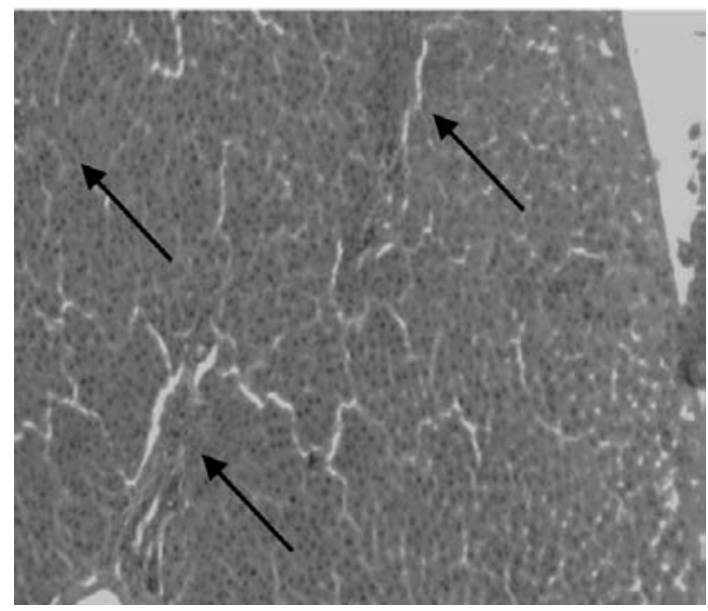

A section of the rat liver tissues administered with $200 \mathrm{mg} / \mathrm{kg}$ of Solignum (Group II) showing inflammatory cells

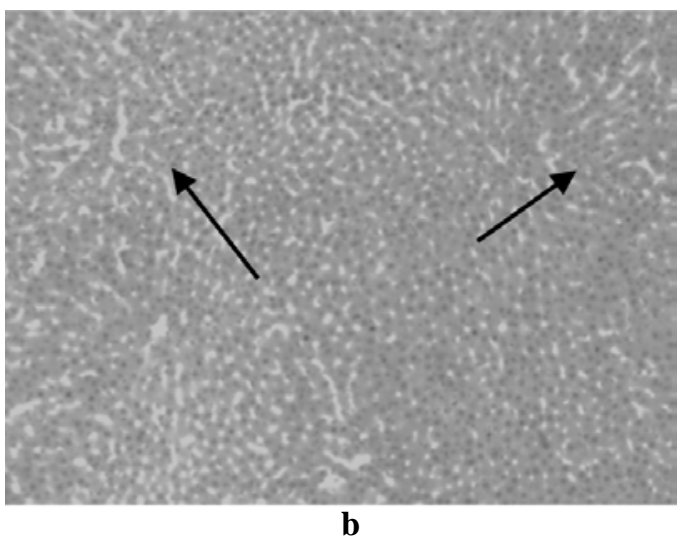

A section of the rat liver tissues administered with $100 \mathrm{mg} / \mathrm{kg}$ of Solignum (Group I) showing mild inflammatory infiltrate

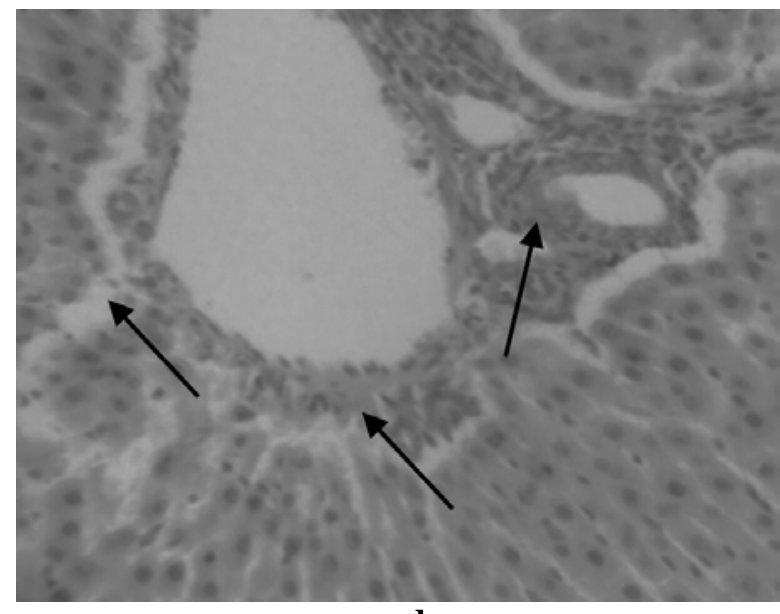

d

A section of the rat liver administered with $400 \mathrm{mg} / \mathrm{kg}$ of Solignum (Group III) showing mild periportal inflammation and cytoplasmic degeneration

Figure 2a-d. Histopathological examination of the liver (H\&E x 400).

The oral administration of the commercial wood preservative-Solignum $^{\circledR}$, a permethrin-containing insecticide, showed no mortality or physical changes up to $1 / 10$ of the higher range of the $L_{50}$ for permethrin in rats. This corroborates earlier reports that the no-observed-adverse-effect-level is greater than $400 \mathrm{mg} / \mathrm{kg} \mathrm{BW}[11,12]$. The study recorded an elevation in the body weight of rats in all test groups, which further buttresses the findings that insecticide exposures may change lipid and glucose metabolism contributing to the development of obesity and type II diabetes
[21, 22, 2]. Furthermore, studies have indicated induced triglyceride (TG) accumulation in adipocytes on exposures to various insecticides [23, 24, 25, 26], and interaction with dietary fat, leading to a change in lipid metabolism and insulin resistance in mice [27, 28, 29, 30]. Variations in body weight gain could be a reflection of toxicity [31]. Therefore, the weight gain of rats treated with Solignum at the end of the second and fourth weeks may be an indication of the adverse effects of sub-chronic administration of Solignum to experimental rats. 


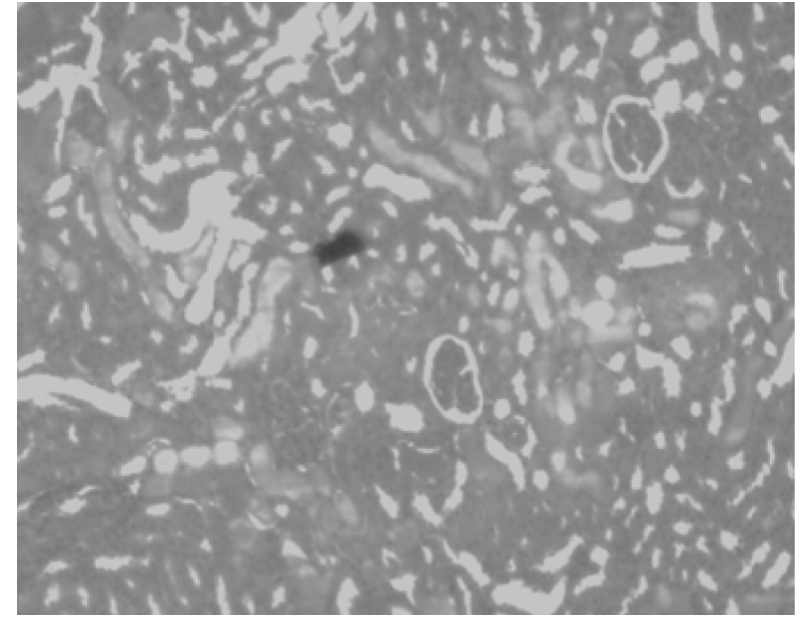

A section of the rat kidney tissues showing normal architecture in the control rats

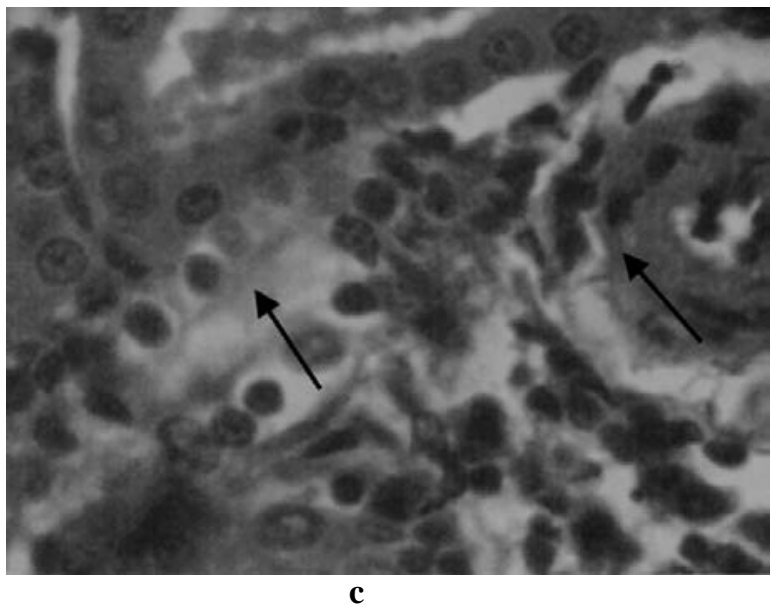

A section of the rat kidney tissues administered $200 \mathrm{mg} / \mathrm{kg}$ of Solignum (Group II) showing inflammatory cells

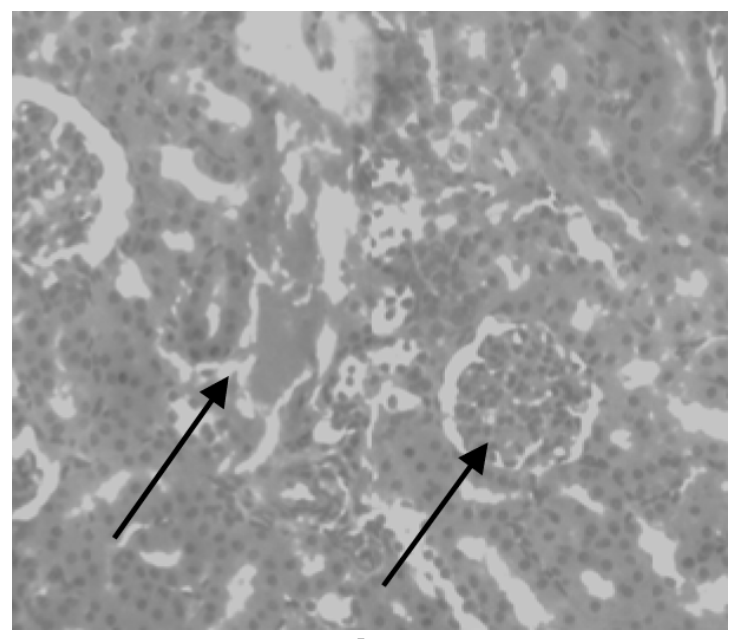

b

A section of the rat kidney tissues administered $100 \mathrm{mg} / \mathrm{kg}$ of Solignum (Group I) showing inflammatory cells and congested vessel

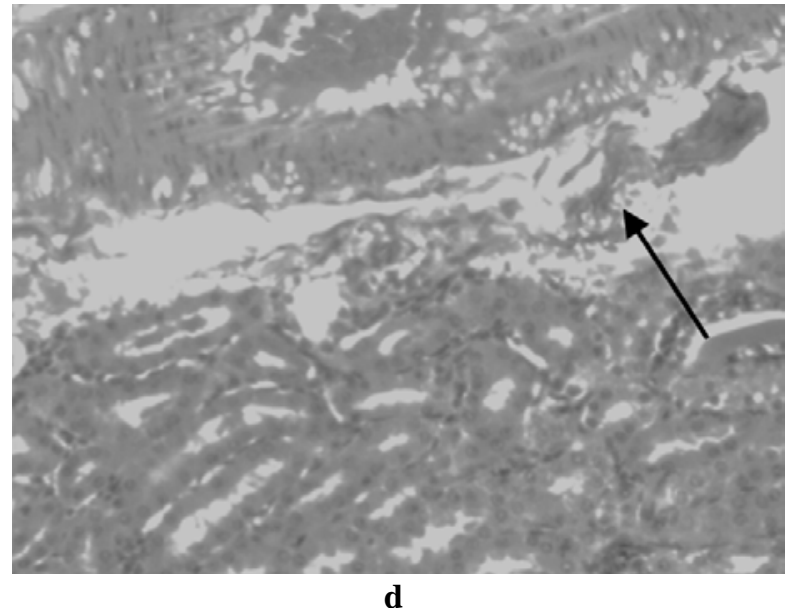

A section of the rat kidney tissue administered $400 \mathrm{mg} / \mathrm{kg}$ of Solignum (Group III) showing interstitial haemorrhage

Figure 3a-d. Histopathological examination of the kidneys (H\&E x 400).

The discoveries from this study partly describe the effects of treatment with different concentrations of Solignum may have had on kidney function. Indices used in the determination of kidney functionality include electrolytes, urea, and creatinine. Electrolytes have been known to manage cellular toxicity [32], fluid distribution, sustain internal and external cellular acid-base balance, maintain osmotic pressure, and to control normal neuromuscular sensitivity [33]. The estimation of sodium and potassium concentration indicates the renal function of the system in question [32]. Estimating serum or plasma urea and creatinine is a vital test of renal function. In this study, there was a marked increase in the $\mathrm{Na}^{+}$and urea concentration in rats exposed to 100 and $400 \mathrm{mg} / \mathrm{kg}$ Solignum when compared to the control, while the $\mathrm{K}^{+}, \mathrm{Cl}^{-}$and creatinine concentrations were significantly reduced in a dose-dependent manner across all groups in comparison to the 


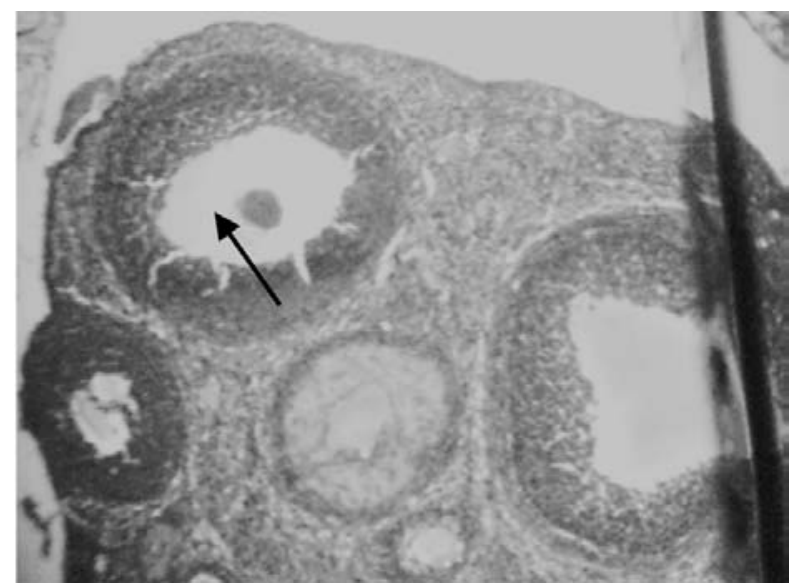

a

A section of the rat ovarian tissues showing normal architecture in the control rats

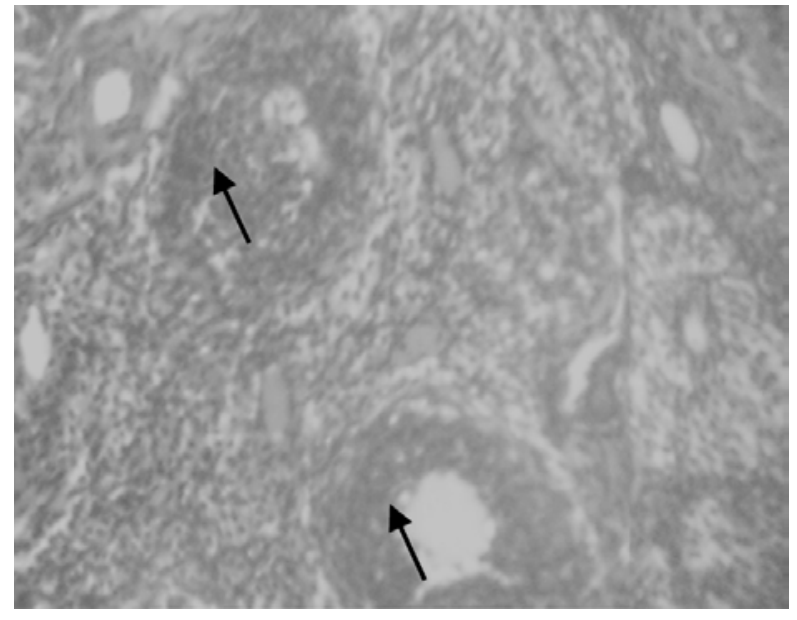

C

A section of the rat ovarian tissues administered with $200 \mathrm{mg} / \mathrm{kg}$ of Solignum (Group II) showing degenerating follicles

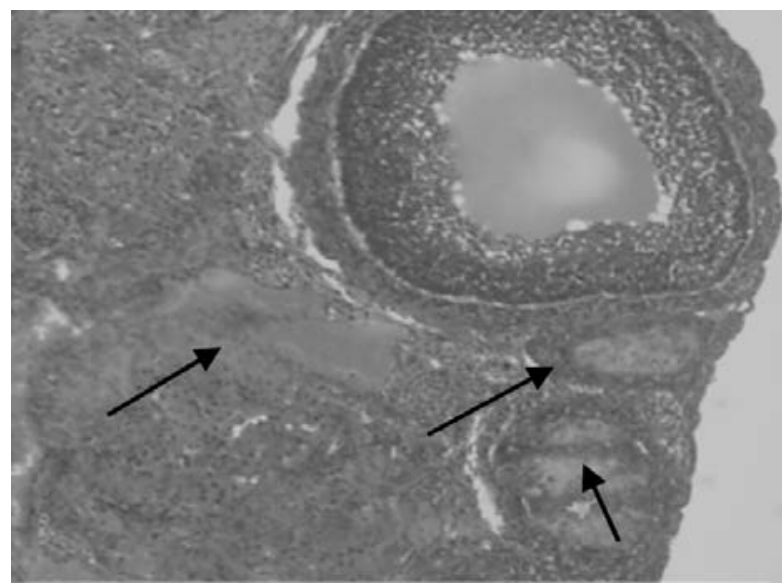

b

A section of the rat ovary administered with $100 \mathrm{mg} / \mathrm{kg}$ of Solignum (Group I) showing atrophic follicles and blood vessel haemorrhage

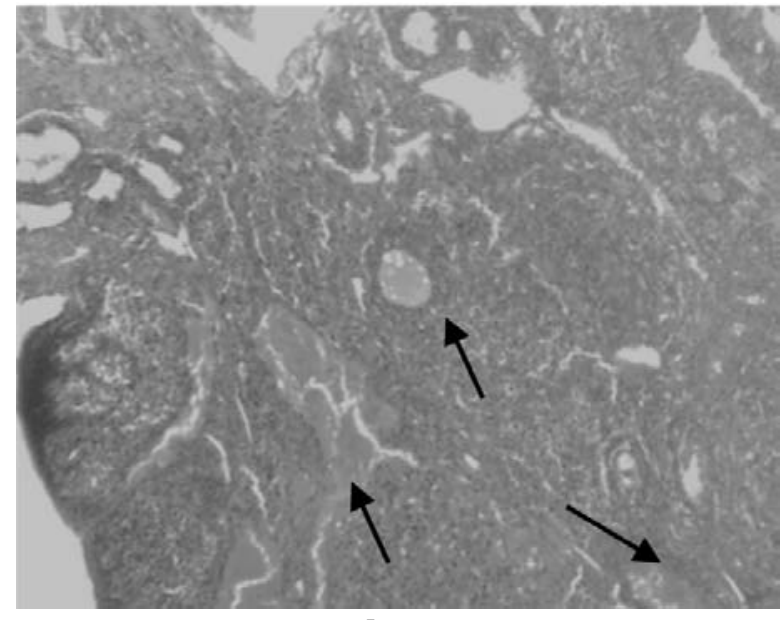

d

A section of the rat ovarian tissues administered with $400 \mathrm{mg} / \mathrm{kg}$ of Solignum (Group III) showing degenerating follicles

Figure 4a-d. Histopathological examination of the ovaries (H\&E x 400).

control group. The marked increase in urea concentration supported the increased urea nitrogen concentration findings of Shah and Iqbal [34], where diazinon exposure resulted in damage to the kidneys. However, both studies deviated in the creatinine concentration, whereas a lower concentration was recorded in the present study. A study by Borzecki et al. [35] also showed a marked increase in urea concentration but a nonsignificant difference in the creatinine levels for the exposure group in comparison with the control group on exposure to $16.6 \mathrm{~g} / \mathrm{kg}$ deltamethrin, also indicating a non-significant effect on the kidneys.

The raised $\mathrm{Na}^{+}$concentration in test groups corroborates the findings of Mondal et al. [36], who reported elevated $\mathrm{Na}^{+}$concentration on the administration of acetamiprid to Wistar albino rats, with a deviation in the $\mathrm{K}^{+}$and $\mathrm{Cl}^{-}$ concentration as observed in the present study. 
A significant reduction in creatinine levels may be an indication that there were no alterations in the functioning capacity of the kidneys for the period of exposure to Solignum. Also, there was an increased level of total bilirubin in treated rats, a possible indication of hyper-bilirubinaemia a useful index for estimation of liver cell damage [37, 38]. Hyper-bilirubinaemia may be attributed to excessive haem destruction and blockage of the biliary tract. This, however, may have led to a mass inhibition of the conjugation reaction and release of unconjugated bilirubin from damaged liver cells [39]. However, the raised total protein, glyceride, and cholesterol values observed in the study did not correspond with the findings of Remia et al. [40]. A possible explanation would be that sub-chronic administration of Solignum had no effects on protein or fatty acid metabolism correlating the increase in weight seen in the test groups. Furthermore, the haematological parameters showed remarkable differences between the control group and the test groups exposed to different concentrations of Solignum, which may be an indication of the adverse effect it has on body fluids. Insecticides have been shown to cause adverse effects in erythropoiesis, thus there may be a drop in RBC, Hct, and Hb parameters [41]. While the RBC, MCV, MCH, and MCHC of test groups were elevated, there was a decrease in haemoglobin concentration and PCV across all groups exposed to different concentrations of Solignum in comparison to the control group. Anaemic conditions are marked by a decrease in the haemoglobin concentration of the blood, which is followed by a reduction in red cell count and PCV, leading to a rise in MCV [42]. Jaffar Ali and Rani [43], also noted that a rise in $\mathrm{MCH}$ and MCV may be linked to a reduction in the $\mathrm{Hb}$ concentration in each cell and destruction of red blood cells, corresponding to the findings of this study, where a fall in $\mathrm{Hb}$ and PCV in all test groups was observed, likely related to a developing anaemic condition which may have resulted from exposures to different concentrations of the wood preservative. The effects pesticides have on the immune system have been extensively reported $[44,45]$. In the present study, the WBC count, platelet, neutrophil, monocyte, and lymphocyte concentrations were assessed. There was an increase in all the parameters except monocyte concentration, which was lower. The white blood cell acts as a defense for the body against external assault from infections and xenobiotic [42], while neutrophils are matured leucocytes vital for protecting the body against diseases and infections by discarding and destroying some bacteria, wastes and foreign substances [46]. On the other hand, lymphocytes are small white blood cells with a specific response to xenobiotic attack. It is particularly helpful in protecting the body against tumors [46]. Following these findings, it could be said that a rise in the WBC count, platelet, neutrophil, and lymphocyte concentrations may have occurred in response to the exposure of the test organism to concentrations of the wood preservative Solignum. The monocytes are known to perform three basic functions: phagocytosis, antigen presentation, and cytokine production [42]. The monocyte concentration in the test groups of this study was significantly reduced in comparison to the control, which may have possibly resulted from the assault posed by the exposure to the wood preservative. The discoveries of the present study corroborate earlier reports of Garg et al. [47], who showed that exposure to small doses of man-made pyrethroid, organophosphates, and chlorinated pesticides led to serious effects on metabolism and immune system of birds.

In this study, histopathological changes were observed in the form of mild periportal inflammatory cells and cytoplasmic degeneration in the liver of the test groups, while the kidneys of the treated groups revealed the presence of inflammatory cells, congested vessel and interstitial haemorrhage. This is related to the findings of Duzguner and Erdogan, [9], which showed that some compounds used in pesticide production can induce oxidative stress leading to the generation of free radicals and may result in changes in antioxidants or free radical scavenging enzyme system. Records also show that the oxidative stress induction potential of insecticides could ultimately result in inflammatory responses [8], accounting for the inflammatory cells observed in the present study. Hossain et al. [48] has also reported the presence of inflammation in a variety of cell types and organisms treated with permethrin. Miller et al. [49] also recorded the ability of insecticides to 
directly or indirectly stimulate important immune mechanisms which could lead to activation of inflammatory responses. Exposure to a range of insecticides is known to accelerate the production of cytokines such as interferon-gamma- $\gamma$ (IFN) and tumour necrosis factor- $\alpha$ (TNF- $\alpha)$ [9, 50, 51]. These go on to explain the revelations of this study that Solignum may have induced oxidative stress or inflammation which may account for the degenerative changes in various organs such as liver and kidney. The kidney histopathology findings of this study are similar to some experimental studies which showed the nephrotoxicity activity of pesticides such as deltamethrin [52] and some organophosphates [53, 34], and organochlorine insecticides [54, 55, 56]. Glyphosphate has also been demonstrated to stimulate epigenetic responses which resulted in kidney damage in rats after long-term exposures to extremely low water concentration of $0.1 \mathrm{ppb}$ of Roundup [57]. Histological examination of the ovaries of the different test groups exposed to concentrations of Solignum showed atrophic follicles, blood vessel haemorrhage and degenerating follicles. This corresponds with the finding of Tomic et al. [58], where Methoxychlor-treated mice caused follicular atresia in the ovary, indicated by reduced concentrations of Follicle Stimulating Hormone (FSH). A study by Kumar et al. [59] also indicated degeneration in graffian follicle and germinal epithelium after exposure to endosulfan.

\section{CONCLUSIONS}

Data from the current study suggest that permethrin, the active ingredient of Solignum, may have caused adverse effects on biochemical parameters and subsequent damage to various organs such as liver, kidney, and ovaries through the generation of reactive oxygen species.

\section{CONFLICT OF INTEREST STATEMENT}

The authors declare that there are no conflicts of interest.

\section{REFERENCES}

1. Environmental Protection Agency (EPA). 2005, Overview of permethrin risk assessment.
2. Xiao, X., Clark, J. M. and Park, Y. 2017a, Food Chem. Toxicol., 105, 456-474.

3. National Research Council (NRC). 1994, Health Effects of Permethrin-Impregnated Army Battle-Dress Uniforms, Subcommittee to Review Permethrin Toxicity from Military Uniforms, Committee on Toxicology, Board on Environmental Studies and Toxicology.

4. Tornero-Velez, R., Davis, J., Scollon, E. J., Starr, J. M., Setzer, R. W., Goldsmith, M., Chang, D. T., Xue, J., Zartarian, V., De Vito, M. J. and Hughes, M. F. 2012, Toxicol. Sci., 130(1), 33-47.

5. Omoregie, E. 1998, Acta Hydrobiol., 40, 287-292.

6. Dikshith, T. S. S. 1991, Toxicology of Pesticides in Animals. CRC Press, Boca Raton, Boston.

7. Soderlund, D. M., Clark, J. M., Sheets, L. P., Mullin, L. S. and Piccirillo, V. J. 2002, Toxicology, 171, 53-59.

8. Kanbur, M., Liman, B. C., Eraslan, G. and Altinordulu, S. 2008, Environ. Toxicol., 23(4), 473-479.

9. Duzguner, V. and Erdogan, S. 2010, Pestic Biochem. Physiol., 97, 13-18.

10. Abdallah, F. B., Slima, A. B., Dammak, I., Keskes-Ammar, L. and Mallek, Z. 2010, Andrologia, 42(3), 182.

11. Tomlin, C. D. S. 2006, The pesticide manual: a world compendium. $14^{\text {th }} \mathrm{Ed}$. Alton: British Crop Production Council.

12. Toynton, K., Luukinen, B., Buhl, K. and Stone, D. 2009, Permethirn Technical Fact Sheet. National Pesticide Information Centre, Oregon State University Extension Services.

13. Organisation for Economic Cooperation and Development (OECD). 1995, Repeated dose 28-day Oral toxicity test method guideline 407 adopted 23.03.1996. In: OECD, Guidelines for testing of chemicals. Paris: Organisation for Economic Co-Operation and Development.

14. McGowan, M. W., Artiss, J. D., Strandbergh, D. R. and Zak, B. A. 1983, Clin. Chem., 39, 538-542.

15. Patton, G. J. and Crouch, S. R. 1977, Anal. Chem., 49, 464-469. 
16. Faulkner, W. R. and King, J. W. 1976, Renal Function In Fundamentals of Chemistry, N. Tietz (Ed.), Philadelphia, PA: W. B. Saunders Co.

17. Galigher, A. E. and Kayloff, E. N. 1971, Essentials of Practical Micro Techniques, Philadelphia, PA: Lea and Febiger.

18. Waggas, A. M. 2013, Global Vet., 10, 524533.

19. John, N. A. and John, J. 2015, Int. J. Clin. Exp. Path., 2, 209-213.

20. Naz, M., Rehman, N., Ansari, M. N., Kamal, M., Ganaie, M. A., Awaad, A. S. and Aqasoumi, S. I. 2019, SPJ., 27, 348-353.

21. Sun, Q. C., Clark, J. M. and Park, Y. 2017a, Toxicol. Environ. Chem., 99, 1283-1303.

22. Swaminathan, K. 2013, Diabetic Medicine, 30, 1268-1271.

23. Kim, J., Park, M. Y., Kim, Y., Yoon, K. S., Clark, J. M., Park, Y. and Whang, K. Y. 2017, J. Sci Food Agric., 97, 5176-5185.

24. Kim, J., Park, Y., Yoon, K. S., Clark, J. M. and Park, Y. 2014, J. Biochem. Mol. Toxicol., 28, 418-424.

25. Park, Y., Kim, Y., Kim, J., Yoon, K. S., Clark, J. and Lee, J. 2013, J. Agric. Food Chem., 61, 255-259.

26. Sun, Q., Qi, W., Yang, J. J., Yoon, K. S., Clark, J. M. and Park, Y. 2016a, Food Chem. Toxicol., 92, 217-223.

27. Sun, Q. C., Qi, W. P., Xiao, X., Yang, S. H., Kim, D., Yoon, K. S., Clark, J. M. and Park, Y. 2017c, J. Agric. Food Chem., 65, 65726581.

28. Sun, Q. C., Xiao, X., Kim, Y., Kim, D., Yoon, K. S., Clark, J. M. and Park, Y. 2016b, J. Agric. Food Chem., 64, 92939306.

29. Xiao, X., Kim, Y., Kim, D., Yoon, K. S., Clark, J. M. and Park, Y. 2017b, Food Chem. Toxicol., 108, 161-170.

30. Xiao, X., Sun, Q., Kim, Y., Yang, S. H., Qi, W., Kim, D., Yoon, K. S., Clark, J. M. and Park, Y. 2018, Food Chem. Toxicol., 111, 405-416.

31. Teo, S., Strlig, D., Thomas, S., Hoberman, A., Kiorpes, A. and Khetani, V. 2002, Toxicology, 79, 183-196.

32. Cheesbrough, M. 2005, District Laboratory Practice in Tropical Countries, Cambridge University Press.
33. Harper, H. A. 1977, Prehled Fysiologicke Chemie. Avicenum, Praha.

34. Shah, M. D. and Iqbal, M. 2010, Food Chem. Toxicol., 48, 3345-3353.

35. Borzecki, A., Nieradiko-Iwanicka, B., Pasternak, K. and Borzecka, H. 2005, Pol. J. Environ. Stud., 14(11), 461.

36. Mondal, S., Ghosh, R. C. and Mukhopadhyaya, S. K. 2011, Toxicol. Ind. Health, 28(5), 422427.

37. Pimple, B. P., Kadam, P. V., Badgujar, N. S., Bafna, A. R. and Patil, M. J. 2007, Indian J. Pharm. Sci., 69, 827-831.

38. Fakurazi, S., Hairuszah, I. and Nanthini, U. 2008, Food Chem. Toxicol., 46, 2611-2615.

39. Wolt, A., Diez-Fernandez, C., Trendelenburg, C. F., Prieto, P., Hany, S. and Trammer, W. E. 1997, J. Pharmacol. Exp. Ther., 280, 1328-1334.

40. Remia, K. M., Logaswamy, S., Logankumar, K. and Rajmohan, D. 2008, Pollut Res., 27(3), 523-526.

41. Köprücü, S., Köprücü, K., Mevlüt, M. S., İspir, Ü. and Pala, M. 2006, Pestic. Biochem. Physiol., 86, 99-105.

42. Hoffbrand, A. V., Moss, P. A. H. and Pettit, J. E. 2006, Essential Haematology. Blackwell Publishing.

43. Jaffar Ali, H. A. and Rani, V. J. 2009, Turk. J. Vet. Anim. Sci., 33, 407-411.

44. Corsini, E., Liesivuori, J., Vergieva, T., Van Loveren, H. and Colosio, C. 2008, Hum. Exp. Toxicol., 27, 671-680.

45. Steerenberg, P., van Amelsvoort, L., Colosio, C., Corsini, E., Fustinoni, S., Vergieva, T., Zaikov, C., Pennanen, S., Liesivuori, J. and Van Loveren, H. 2008, Hum. Exp. Toxicol., 27, 701-707.

46. Abbas, A. K. and Lichtman, A. H. 2003, Cellular and Molecular Immunology, Philadelphia: Saunders.

47. Garg, U. K., Pal, A. K., Jha, G. J. and Jadhao, S. B. 2004, Int. Immunopharmacol., 4, 1709-1722.

48. Hossain, M. M., Liu, J. and Richardson, J. R. 2017, Toxicol. Sci., 155(1), 112-123.

49. Miller, R. L., James-Kracke, M., Sun, G. Y., and Sun, A. Y. 2009, Neurochemistry, 34, 55-65. 
50. Alluwami, A. M. and Hussein, Y. 2007, Toxicology, 236, 123-131.

51. Ikizcelli, I., Yurumez, Y., Avsarogulari, L., Kucuk, C., Sozuer, E. M., Soyuer, I., Yavuz, Y. and Muhtaroghu, S. 2005, Regul. Toxicol. Pharmacol., 42, 260-264.

52. Chargui, I., Grissa, I., Bensassi, F., Hrira, M. Y., Haouem, S., Haouas, Z. and Bencheikh, H. 2012, Biomed. Environ. Sci., 25, 672-683.

53. Tripathi, S. and Srivastar, A. K. 2010, Toxicol. Indus Health, 26, 439-447.

54. Choudary, N., Sharma, M., Verma, P. and Joshi, S. C. 2003, J. Environ. Biol., 24, 305-308.

55. Sonne, C., Wolkers, H., Leifsson, P. S., Jenssen, B. M., Fuglei, E. and Ahlstrom, O. 2008, Chemosphere, 71, 1214-1224.
56. Sobel, E. S., Gianni, J., Butfiloski, E. J., Croker, B. P., Schiffenbauer, J. and Robert, S. M. 2005, Environ. Health Perspect., 113, 322-328.

57. Mesnage, R., Arno, M., Costanzo, M., Malatesta, M., Seralini, G. E. and Antoniou, M. N. 2015, Environ. Health, 14, 70.

58. Tomic, D., Frech, M. S., Babus, J. K., Gupta, R. K., Furth, P. A., Koos, R. D. and Flaws, J. A. 2006, Toxicol. Sci., 93(1), 196204.

59. Kumar, R., Gupta, D., Mukul, S., Singh, A. K., Kumar, A., Ali, Md., Nath, M. A., Kumar, A. and Singh, J. K. 2012, Int. J. Pharm. Biol. Arch., 3(3), 617-621. 